Marko Pavlović $^{{ }^{\star}}$, Radica Bojičić ${ }^{2}$, Milijanka C. Ratković ${ }^{3}$ ${ }^{1}$ Univerzitet Union Nikola Tesla, Faculty of Business Studies and Law, Belgrade, Serbia 2 University of Prishtina, Faculty of Economics, Pristina

${ }^{3}$ Univerzitet Union Nikola Tesla, Faculty of Business Studies and Law, Belgrade, Serbia and University of Donja Gorica, Faculty of Sport Management, Podgorica, Montenegro

\title{
Customer satisfaction with postal services in Serbia
}

DOI: 10.7595/management.fon.2018.0005

\begin{abstract}
Research question: This study examines users' satisfaction with the postal service in Serbia using a questionnaire measurement. Motivation: the Post of Serbia operates both with private and business clients, with whom it has long-term relationships not only in terms of sending and receiving parcels, but also with new and modern services. Due to the growing competition on the market, the question arises how to place the Post of Serbia on the market in the future. Data: Primary data of postal services, new postal services, as well as a custom questionnaire for examining users' attitude towards postal services intended for private clients. Tools: Method of survey, Descriptive statistics, Method of analysis and Content analysis. Findings: The satisfaction of users of postal services is an important element of the perseverance and development of the Post of Serbia. Contribution: Quality review of postal services in the opinion of the private users. Obtained gap between users satisfaction and needs and further directions in which the Post of Serbia should be developed according to the user's opinion.
\end{abstract}

Key words: Post, competitiveness, expectations of postal services users, perception of users of postal services, Servqual model.

JEL Classification: BM31, Y1, C1

\section{Introduction}

The market of postal services is constantly evolving and changing (Sarac, Kopic, Mostarac, Kujacic \& Jovanovic, 2016). Following the example of Europe after the end of its monopoly status, the Post begins to pay attention to the needs of its users. Postal operators are affected by the changes and the impact of globalization. In order to survive on the market, companies must observe the needs and demands of their users, analyze them regularly, and come up with quick and quality solutions (Lee \& Yang, 2013). This situation raises the question of how to improve their business. Increasing the quality of services inevitably leads to an increase in the value of services. Measuring customer satisfaction is one of the important factors for determining the quality of services, and hence for improving the business results. The challenges of measuring the quality of services are usually related to the nature and meaning of services, and not only to the demands of change and pressure from the competition. The latter is based on the specific features of services. The quality of services is an important factor for the business success of the Post today, as well as for the business success of other companies. There is a number of ways of defining services, the most commonly used ones being: the first which is based on activities and performance as the basis for defining services (Hill \& Alexander, 2006), and the one based on the characteristics of services (Berry \& Jams, 1995). The difficulty of defining the desirable quality of services lies primarily in the changing nature of user demands. Namely, the requirements of the postal service users are constantly increasing, and in order for the Post to expand its services and survive, it must constantly monitor the demands of the users in accordance with their needs. 
To that end, it is necessary to conduct continuous research and to implement the obtained information into business decisions. When analyzing the behavior of Post service users, one should bear in mind that the basic elements that influence their expectations are: previous experience, environmental recommendations and promotional promises.

The basic aspects that influence consumer expectations are user needs, previous experience, recommendations and promotional promises. Also, the internal content, that is, the interior has a direct impact on the expectations of the users.

Scientific and technological research conducted by foreign authors indicate a growing interest in studying the quality of services and user satisfaction, not only in the field of postal services, but also in other organizations that provide services. Unlike these foreign authors, domestic authors have rarely studied this issue and have taken only a few aspects into consideration. (Kabene, Orchard, Howard, Soriano \& Leduc, 2006). At the same time, the advancement of technology imposed new methods of doing business, as well as the reversal of the relationship between users and the companies themselves (Kujacic, Unterberger, Sarac\&Jovanovic, 2014). Taking this fact into consideration, the need to increase service efficiency and quality is a critical strategic focus, given the increasing technological competition, rising operating costs, and changing customers' needs and expectations. (Pitia et al., 2013). We can see that there is a theoretical and practical justification for the research presented in this paper. Research results can help postal service operators take the necessary measures to fill the gaps between expected and perceived quality, in order to improve the performance of existing services.

In accordance with the research objective, the following hypotheses have been defined:

Initial hypothesis: Postal service users have higher expectations than those the quality of which is being provided.

\section{Secondary hypotheses:}

$\mathrm{H} 1$ Postal service users expect more from the dimension of the quality of "Reliability" H2 Postal service users expect more from dimension of the quality of "Trust"

H3 Postal service users expect more from the dimension of the quality of "Empathy" H4 Postal service users expect more from the dimension of the quality of "Responsibility" H5 Postal service users expect more from the dimension of the quality of "Tangibility"

The research is based on the Servqual model adapted to the Post. The Servqual model provides us with the opportunity to measure the quality of the service based on five dimensions, namely: Tangibility, Trust, Reliability, Responsibility and Empathy (Sokolov-Mladenovic\&Cuzovic, 2015). The Servqual methodology is based on GAP number 5, i.e., comparing subsequent perceptions with preliminary expectations, of course, from the point of view of users (Pindzo\&Loncar, 2013).

A small number of scholarly research, to date, has been carried out to classify quality elements and full features of services and their associations with customer satisfaction (Roopchund\&Boojhawon, 2014). SERVQUAL methodology is an implemented and tested methodology primarily within the commercial sector (Kaye\&Dyason, 2013). Bryaland and Curry (2001) concluded that the literature clearly supported the use of SERVQUAL in the public sector. There are a number of researchers who have adopted SERVQUAL for measuring service quality in the banking sector (Ladhari, Ladhari\&Morales, 2011; Rakesh, 2012; llyas, 2013; Panda \& Kondasani, 2014; Roslan, Nor \& Wahab 2015; Garrard, Francesca \& Narayan, 2013; Kiumarsi, Jayaraman\&Mohd-Isa 2015). Based on the insights into literature, the authors decided on this model of quality service measurement in the Post of Serbia.

During the research, certain limitations emerged from the model itself, but also due to the fact that the expected number of responses was not obtained and due to the fact that the answers in some questionnaires were incomplete. More than 2,000 e-mails or questionnaires have been sent. In all, 430 responses were collected, 30 respondents did not give a complete answer, i.e., they did not complete the questionnaire to the end, so these answers were excluded from processing. It should be noted that this method of data collection has certain disadvantages, especially because we are talking about the available probabilistic pattern that does not meet strict criteria of representativeness regardless of size (Evans \& Anil, 2005).

On the other hand, there are various advantages of this method of collecting data that should be emphasized, such as cost reduction, inability to influence response and comfort of respondents (Milosevic\&Rodic, 2015). 


\section{Motivation for Research}

Postal services, i.e., the clearance, sorting, transportation and delivery of postal items, still remain an important part of the country's economic and social development (Pilinkiene, Deltuvaite, Daunoriene \& Gaidelys, 2017). The trend of continuous development of new services has been very popular in recent years in postal and other service-oriented companies and is conditioned by the demands and desires of the users (Maricic, Veljkovic\&Djordjevic 2012). The achievements of modern information technologies and their applications have significantly affected the service domain. The application of information technologies reduces operating costs and interest margins; improved quality of services, new services and products are being created, and risk management becomes more efficient (Vunjak\&Kovacevic, 2011). The existence of a universal postal service means that the market cannot provide an adequate level of service or the full range of products, or at least not at an affordable price level for all users in its absence (Ambrosini, Boldron, \& Roz, 2014). One example of a service that positively affects the satisfaction of users in the Post is providing information on the waiting time. Waiting time information positively affects customer satisfaction when it comes to waiting time (Bielen\&Demoulin, 2007). Users are familiar with the time spent in waiting and use this experience to adjust their needs to the average waiting time in the facility after the service is performed (Jovanovic, Grbic, Bojovic, Kujacic\&Sarac, 2015). Based on this, the degree of customer satisfaction can be presented as the ratio of the acceptable and expected waiting time according to previous experience (Acker, Haxholdt\& Larsen, 2013).

The main intention of the Post is to attract new users and to maintain good relations with the existing users, or to expand the value, especially when it comes to offering new products and services. The Post of Serbia is changing its business philosophy that was initially passive and is now slowly becoming proactive in seeking new ways of doing business (Blagojevic, Selmic, Macura\&Sarac, 2013). Innovation in business primarily relates to technologies related to the transfer of money and packages. The distribution network for the realization of information and business contacts that are available to banks and post offices includes ATMs, SMS services, Internet services and other. Therefore, with an increasing importance of internationalization of the business and quality system, consumers are given a central place in business operations. At the same time, consumer awareness is enhanced with the process of technological development and globalization (Grubor\&Milicevic, 2015).

These changes imply a demand for constant improvement of customer satisfaction, which directly affects the life cycle of products and services. How long the product life cycle will be, whether it is a commercial repositioning of a stagnating brand or not, and what the level of consumption will be, depends on whether consumers are stimulated. One of the biggest challenges for carrying out academic research is customer dissatisfaction (Mahapatra, 2014). Successful marketing strategies and business success in the market depend on users, as well as success in the long run. Established partnerships with customers are mutually beneficial, both for themselves and for the company (Milisavljevic, 2009).

In today's business conditions, it is very difficult to attract new users. Today's business environment is radically different from that in the past in most aspects (Ratkovic, Krasulja\&Garaca, 2013). It is therefore necessary to work on discovering the motivation factors which are part of the psychological determinants of making decisions. Companies that focus on customer satisfaction are focused on satisfying their needs, not on products. Researching motivation is important in order to understand why users are looking for, buying and using certain types and brands of products and services. A motivated user is ready for action, i.e., purchasing of offered products and services. Motivation is an internal force that cannot be seen, but it stimulates and guides consumer behaviour in the desired direction. Consumer behavior in the purchasing process has its own purpose, i.e., the goal. The purpose and goal is to meet certain needs or desires. However, consumer behaviour changes over time under the influence of different factors, which indicates the need for continuous research of motivation. If you understand consumers' motives, half of the work is done in order to adequately meet the needs and achieve sales and make profit (Maricic, 2005).

Provision of basic postal financial services contributes to global economic development, and hence to social development, and plays a very important role in improving the living standard of the population. A large number of postal operators in the world direct a significant portion of their activities on providing e-services to their clients (Sarac, Kujacic\&Jovanovic, 2013). It is necessary to point out that the Post of Serbia is investing increasing efforts into finding, as well as into maintaining good business relations with their customers. Post offices are changing their business philosophy, which was initially passive, and now they have become proactive in finding new jobs or users. Innovations in the business of the Post of Serbia are primarily related to the implementation of new technologies, the transfer of money and shipments. The modern 
marketing environment includes the use of innovations in the field of information and communication technologies and appropriate solutions in the form of software and other IT solutions (Grubic\&Ratkovic, 2012; Grubic, Ratkovic\&Paunovic, 2013). Distribution networks used to create information and business contacts are made up of ATMs available to banks and post offices, SMS services available to banks and post offices, Internet services, with the requirements of the modern environment.

Having in mind the fact that the market consists of many different elements that have mutual impact and effect on the company's operations, the ability to create strategic performance can include all options, from selecting a homogeneous segment and placement of products, to the selection a large number of different segments and presenting more products (Ratkovic, Grubic\&Tasic, 2011). The choice of strategy can limit the possibilities of improving the satisfaction of target groups or individual users, which implies the importance of creating flexible structures of relations between postal service users and the Post. In order to increase user satisfaction it is necessary to implement new achievements of modern technologies, which affects the development of the entire economy. A modern society cannot be imagined without an efficient postal system (Dobrodolac, Ralevic, Svadlenka\&Radojicic, 2016). Postal services represent a support to the citizens. We are witnessing the fact that the Post of Serbia successfully cooperates with large institutions and facilities providing its basic and additional services.

Let us here just mention a number of them: sales of free shares to citizens lasting for more than ten years, activities related to restitution, cooperation with the Ministry of Trade and Tourism, i.e., holiday vouchers for vacations in Serbia, as well as the cooperation with the National Health Insurance Fund. This kind of cooperation helps a lot of citizens, i.e., recipients of services. In the future, such services can become universal postal services. The very availability itself will allow this. Universal postal service is a set of measures aimed at providing users with the same level of service at an affordable price in all places on a territory (Dobrodolac, Ralevic, Svadlenka\&Radojicic, 2016). Some authors have analyzed how a universal postal service can use its specifics and gain an advantage over other competitors (Dobrodolac, Lazarevic, Svadlenka\&Zivanovic, 2016). The main characteristics of the environment are permanent changes, which pose risks, but also opportunities that can bring advantages over the competition (Knezevic, Macura \& Bojovic, 2014). Therefore, it should be made clear that if the existing universal postal service provider is protected by monopoly, competition will not be sufficiently developed, nor the quality of the service provided (Miletic, 2013). A universal postal service is a set of basic postal services that are continuously carried out on the territory of the Republic of Serbia, within a certain quality at favorable prices and under the same conditions for all users without discrimination (the Regulation on General Conditions for the Provision of Postal Services, "Official Gazette of RS", number 24/2010, 58/2010, 2/2011, 13/2011, 65/2011, 93/2013 and 97/2015).

Postal services include transfer of packages, marketing services, including announcements, advertisements, direct mail, mail, personalized postage stamps, marketing services of the Post of Serbia, telemarketing, telephone sales, commercial SMS services, mailboxes, hybrid mail services etc. Financial services include payment, money transfer, banking services, remittances, e-services; cash express services, ATMs, free shares, banking services and the exchange office of the Post Office of Serbia. There are additional services such as logistics, including IT services, philately, product sales and other services realized in cooperation with other organizations (for more information visit www.posta.rs). A market relationship that includes relationships with employees and relationships with customers, as well as other groups of participants in the supply chain that provide value to the end user, is, in fact, a concept that modern marketing places as a central task, and which is just what the Post is doing.

In the eighties, Parasuraman, Zeithaml, and Berry (1988) noticed the need to measure the quality of the service and conducted extensive research and examined the significance of service quality (Hill\&Alexander, 2006). Measuring quality is important for the Post to operate because it is an indicator of whether the service should be changed or not. Service quality should be a priority for service providers. Customer satisfaction is becoming one of the most important elements for long-term business. The essence of the new concept of the universal postal service lies in improvement of the final phase of the transfer, bearing in mind that the highest costs are related to the delivery phase (Ralevic, Dobrodolac\&Markovic 2016). Bass's diffusion model describes the process of accepting new services through the interaction between existing and potential users (Bass, 1969). In developed countries, some Post offices are privatized, but the Post of Serbia is not ready for this step yet. Still, some postal services can go towards privatization, but in line with European standards and procedures. There is no clear mandate for the privatization of the posts at the time being (Petrovic, 2016). In developed countries, the Post undergoes an implamantation of a strategy of growth, and with this becomes a competitor. The model of a market-oriented state enterprise is the most promising for postal operators' transformation into an entity capable of providing universal service at acceptable prices in the 21 st century economy (Petrovic, 2016). 
Privatization is a process of transferring ownership of a postal service provider from the public sector (stateowned) into the private sector. The predecessor of privatization is corporatization which turns postal state agencies into corporations (Jaag, 2014). At the moment, the Post of Serbia will not be privatized, although some economic analysts believe that this step will improve its business. The restrictions are derived from the defined way of providing universal services and their defined scope according to the directives of the European Parliament and the Council $(1997,2002,2008)$, but also according to specific conditions in individual countries (Matuskova \& Madlenakova, 2017). The economic theory generally considers privatization as a change of ownership, i.e., privatization of materials and does not include explicitly formal privatization, which is surprising (Schuster, 2013).

The changing environment of the postal sector over the last decade has increased the urgency for governments worldwide to re-examine regulations governing how their public postal administrations operate (Pitia, Singh \& Postal, 2013).

The need to increase the efficiency of services and quality in the Post of Serbia is a key strategic focus together with that the services provided should be made better than competitors'. Certainly the capacity of the postal network is a unique strategic advantage of any post, since it provides access to services in the internal market, while at the same time it supports expansion and global integration (Blagojevic, Selmic, Macura \&Sarac, 2013).

\section{The Research Sample}

The survey was conducted in the period from the beginning of November to the end of January 2017. The total sample consisted of 400 participants, citizens of the Republic of Serbia. In relation to gender, the majority of the sample (two-thirds) consists of female respondents $(66.0 \%)$ and one-third of the respondents were male (34.0\%). The sample was balanced by age: $20,0 \%$ of respondents is represented in all five age categories (from 17 to 24 years, 25 to 35 years, 36 to 55 years, 56 to 65 years of age and over 65 years of age).

When it comes to professional qualification of the respondents (Chart 1), most respondents in the sample have a university degree (33.3\%). 32.8\% of them completed their secondary school, and a quarter of the respondents $(25.8 \%)$ has college education. $5.0 \%$ of respondents have a Master's degree, while $3.3 \%$ of respondents have a doctoral degree. Respondents with a degree in elementary education are not represented in the sample.

In addition, most respondents almost two-thirds reside in Sumadija and Western Serbia (60.8\%), in relation to the place of residence (Chart 2). $17.8 \%$ of respondents are from Vojvodina, slightly less (16.8\%) from Belgrade, while $4.8 \%$ of respondents are from South and East Serbia. Respondents from the region of Kosovo were not included in the sample.

Chart 1: Sample structure according to education

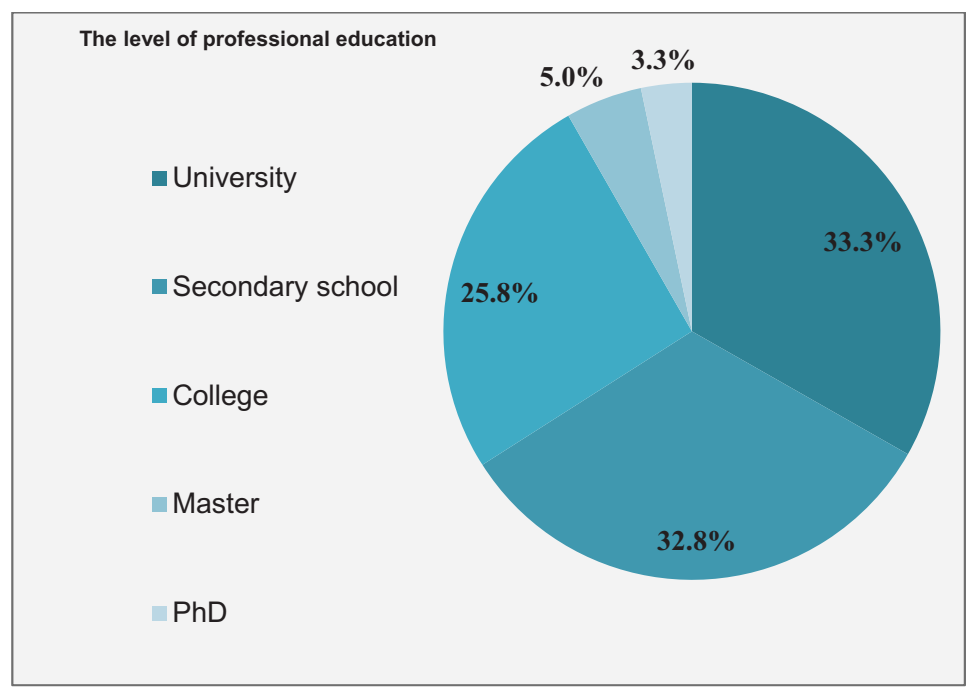

Source: Authors' calculations 
Chart 2. Sample structure according to place of residence

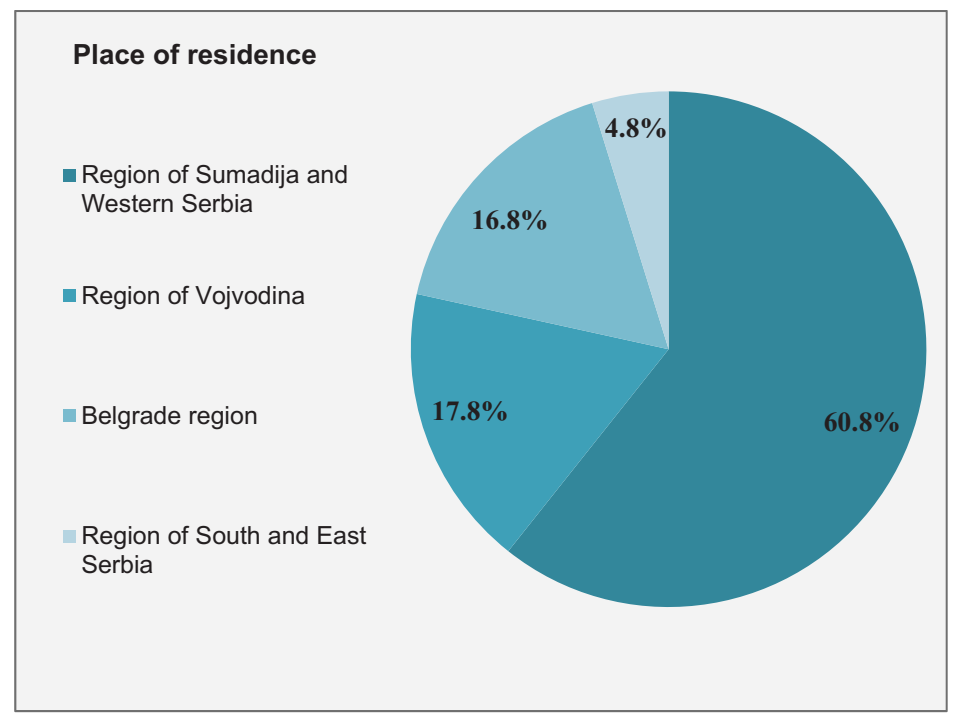

Source: Authors' calculations

In relation to the marital status of respondents, slightly more than half of respondents $(53.8 \%)$ are single and the remaining $46.3 \%$ are married. In the sample there were no divorced or widowed respondents.

When it comes to the height of monthly income (Chart 3), the structure of the sample showed that most respondents, almost half of them (47.0\%), do not want to disclose the amount of their monthly income. In addition, $13.0 \%$ of respondents have a RSD 40,001-50,000 monthly income, $12.0 \%$ of them have a RSD $26,001-40,000$ monthly income and $11.5 \%$ of respondents have an income higher than RSD 60,000. In addition, $10.0 \%$ of respondents have a RSD $15,001-25,000$ monthly income, and $6.5 \%$ of respondents have a RSD 50,001-60,000 monthly income.

Chart 3. Sample structure according to monthly income

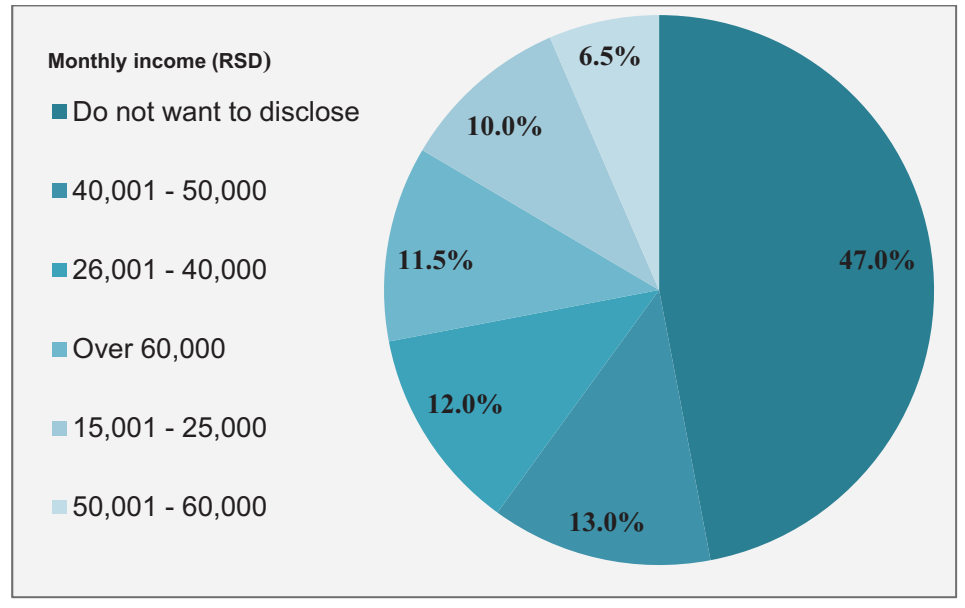

Source: Authors' calculations

When it comes to the social status of the respondents (Chart 4), nearly two-thirds of the respondents are employed $(64.0 \%), 30.3 \%$ of them study, $3.8 \%$ are retired and $1.0 \%$ of the respondents are unemployed or farmers. 
Chart 4: Structure of the sample according to social status

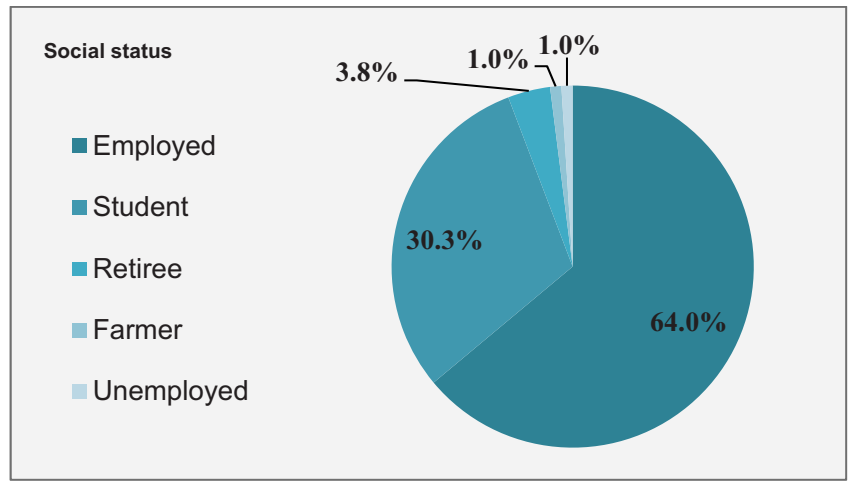

Source: Authors' calculations

\section{Research Results}

It is necessary first to check the Reliability of the used instruments before we begin with the presentation of the research results. Scales that measure the expected and perceived attributes of postal services and a mismatch between expected and perceived services (Gap model) were used. Each used scale has 27 questions grouped into 5 dimensions or attributes of services: Tangibles, Reliability, Responsiveness, Assurance and Empathy. Both scales are Likert-type with a five-choice answers, from strongly disagree (1) to strongly agree (5).

Table 1: Reliability of the Expected attributes of service scale and Perceived attributes of service scale

\begin{tabular}{|c|c|c|}
\hline Scale & $\begin{array}{c}\text { Cronbach's alpha } \\
(\boldsymbol{\alpha})\end{array}$ & $\begin{array}{c}\text { Number of items } \\
(\mathrm{N})\end{array}$ \\
\hline Expected attributes of service & 0.813 & 27 \\
\hline Perceived attributes of service & 0.950 & 27 \\
\hline
\end{tabular}

Source: Authors' calculations

Table 1 presents the Reliability of the used instruments (scales). Very high Reliability coefficients for both scales were obtained: the scale of Expected attributes $\alpha=0.813$, and for the perceived attributes of service $\alpha=0.950$. Both used scales have acceptable Reliability while obtained coefficients are considered to be very high.

As already mentioned, the study examines the discrepancy between the expected and perceived attributes of postal services (Servqual model). Inconsistency is expressed by divergences obtained on the expected attributes of postal services in relation to the perceived attributes of postal services.

Table 2: Prominence of expected and perceived attributes of postal services on the entire sample (Servqual model)

\begin{tabular}{|l|c|c|l|c|c|c|}
\hline \multicolumn{1}{|c|}{$\begin{array}{c}\text { Expected } \\
\text { attributes }\end{array}$} & $\boldsymbol{A S}$ & $\boldsymbol{S D}$ & $\begin{array}{c}\text { Perceived } \\
\text { attributes }\end{array}$ & $\boldsymbol{A S}$ & $\boldsymbol{S D}$ & Divergence \\
\hline Tangibles & 4.60 & $\mathbf{0 . 3 1 9}$ & Tangibles & $\mathbf{3 . 4 4}$ & 0.666 & 1.16 \\
\hline Reliability & $\mathbf{4 . 6 6}$ & $\mathbf{0 . 3 7 0}$ & Reliability & 3.36 & 0.748 & $\mathbf{1 . 3 0}$ \\
\hline Responsiveness & 4.21 & 0.423 & Responsiveness & 3.03 & 0.750 & 1.18 \\
\hline Assurance & $\mathbf{4 . 1 5}$ & 0.617 & Assurance & $\mathbf{2 . 9 0}$ & 0.715 & 1.25 \\
\hline Empathy & 4.36 & 0.511 & Empathy & 3.14 & 0.751 & 1.22 \\
\hline Average & 4.40 & 0.323 & Average & 3.17 & 0.628 & 1.23 \\
\hline
\end{tabular}

Source: Authors' calculations 
Table 2 illustrates the severity of scores on subscales of expected and perceived attributes of postal services, as well as an aggregated average of both scales. The resulting scores show that the highest prominence on the subscales of the expected attributes was obtained for the Expected Reliability dimension (Average Score $=4.66$ ), and the lowest expression was obtained for the expected Assurance dimension (Average Score $=4.15$ ). On the scale of perceived attributes of postal services, the highest score was obtained for the perceived Tangibles dimension (Average Score=3.44), while the lowest score was obtained for the perceived Assurance dimension (Average Score=2.90). Divergences in all subscales of the expected attributes in relation to the perceived attributes of postal services were obtained using Servqual model. The biggest divergence was perceived for the Reliability dimension (1.30) and the lowest divergence is related to the Tangibles dimension (1.16) (Chart 5).

Chart 5: Divergences in measured dimensions obtained by applying Servqual model

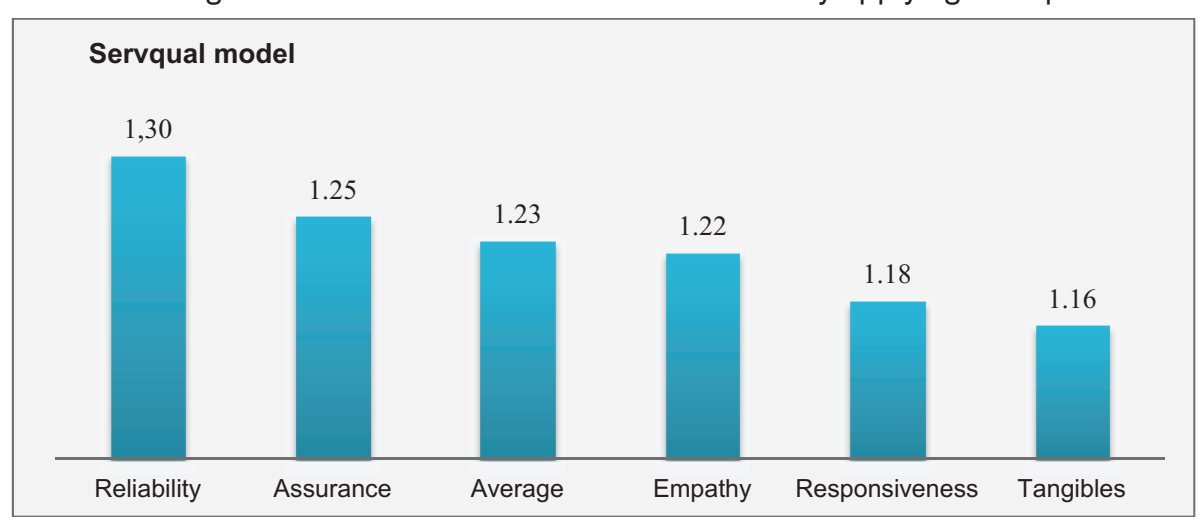

Source: Authors' calculations

The relevance of differences was tested in the subscales of result expression of Expected and Observed attributes of postal services using the non-parametric test, the Wilcoxon signed-rank test, after presenting the severity scores and differences obtained by using the Servqual model. The results show that there are statistically significant differences for all five dimensions of the scales of Expected and Observed attributes of postal services, as well as aggregated averages of the entire scales. All of the obtained severity differences have a negative sign, which is in accordance with the results of the previous table (Table 2). The biggest difference between Expected and Observed attributes of postal services was obtained for the aggregate average scale, i.e., the Reliability dimension, while the smallest difference was observed for the Assurance dimension according to the $Z$ score height.

In addition to testing the difference in Expected and Observed attributes of postal services, i.e., application of the Servqual model, this study includes differences in the severity of the measured dimensions in relation to gender, age, residence, education level, marital status, monthly income level and social status of the respondents.

Table 3: The significance of divergences in the prominence of results on the expected and perceived attributes subscales depending on the gender of the respondents

\begin{tabular}{|l|c|c|l|c|c|}
\hline Expected attributes scale & $\boldsymbol{Z}$ & $\boldsymbol{p}$ & \multicolumn{1}{|c|}{$\begin{array}{c}\text { Perceived attribute } \\
\text { scale }\end{array}$} & $\boldsymbol{Z}$ & $\boldsymbol{p}$ \\
\hline Tangibles & -0.096 & 0.924 & Tangibles & -1.020 & 0.308 \\
\hline Reliability & -2.969 & $0.003^{\star \star}$ & Reliability & -0.067 & 0.946 \\
\hline Responsiveness & -1.587 & 0.113 & Responsiveness & -2.860 & $0.004^{\star *}$ \\
\hline Assurance & -0.867 & 0.386 & Assurance & -2.070 & $0.038^{\star}$ \\
\hline Empathy & -0.427 & 0.669 & Empathy & -5.250 & $0.000^{\star \star}$ \\
\hline Average & -0.131 & 0.896 & Average & -1.297 & 0.195 \\
\hline
\end{tabular}

$d f=400 ; p<0.01 * * ; p<0.05 * ;$ Source: Authors' calculations 
Table 3 shows the significance of divergences in the prominence of the results on measured subscales of expected and perceived attributes of postal services, as well as the significance of divergences in the cumulative averages of both used scales. Significance was tested with the help of the Man Mann-Whitney $Y$ test, and is presented as a height of $Z$ scores and the level of significance ( $p)$. Statistically significant divergences with respect to gender were obtained for the Expected Reliability dimension $(Z=-2.969, p=0.003)$. The resulting divergence is high and significant at $p<0.01$ level. The subsequent analysis showed that male subjects had significantly higher averages than female respondents regarding the Expected Reliability dimension.

Significant divergences in scores are obtained for the perceived Responsiveness dimension $(Z=-2.860$, $p=0.004)$ and perceived Empathy $(Z=-5,2502,860 ; p=0.000)$, as well as the perceived Assurance dimension $(Z=-2,070 ; p=0.038)$. The first two divergences were statistically significant at the high $p<0.01$ level, while the third significant divergence exist at the $p<0.05$ level. The subsequent analysis showed that male respondents recorded higher scores when it comes to Perceived Responsiveness and Perceived Assurance, while female respondents recorded significantly higher scores for the perceived Empathy dimension.

Table 4: The significance of divergences in the prominence of results on the subscales of Expected and Perceived attributes of postal services depending on the age of respondents

\begin{tabular}{|l|c|c|l|c|c|}
\hline \multicolumn{1}{|c|}{$\begin{array}{c}\text { Expected attributes } \\
\text { scale }\end{array}$} & $\chi^{2}$ & $\boldsymbol{p}$ & $\begin{array}{c}\text { Perceived attributes } \\
\text { scale }\end{array}$ & $\chi^{2}$ & $\boldsymbol{p}$ \\
\hline Tangibles & 3.116 & 0.539 & Tangibles & 13.225 & $0.010^{* *}$ \\
\hline Reliability & 10.854 & $0.028^{\star}$ & Reliability & 11.178 & $0.025^{*}$ \\
\hline Responsiveness & 6.057 & 0.195 & Responsiveness & 7.882 & 0.096 \\
\hline Assurance & 0.642 & 0.958 & Assurance & 2.081 & 0.721 \\
\hline Empathy & 2.550 & 0.636 & Empathy & 4.568 & 0.335 \\
\hline Average & 0.666 & 0.956 & Average & 5.530 & 0.237 \\
\hline
\end{tabular}

$\mathrm{df}=400 ; p<0.01 * * ; p<0.05 * ;$ Source: Authors' calculations

Table 4 shows a significant divergence between the results obtained on the subscales of expected and perceived attributes of postal services, as well as divergences in the cumulative averages for both scales in relation to the age of respondents. Significance was tested using Kruskal-Wallis test and expressed through $X^{2}$ coefficient and the significance $(p)$. A statistically significant divergence was obtained for the Expected Reliability dimension $\left(x^{2}=10.854, p=0.028\right)$. The resulting divergence in results is significant at $p<0.05$ level, while a subsequent analysis showed that respondents from the age group 36 to 55 years had significantly higher scores than respondents in other age groups. On the dimensions of the scale of perceived attributes, statistically significant divergences in severity scores were obtained for subscales of perceived Tangibles $\left(X^{2}=13.225, p=0.010\right)$ and perceived Reliability $\left(X^{2}=11.178, p=0.025\right)$. The first obtained divergence is high and significant at $p<0.01$ level and the other is significant at the $p<0.05$ level. Further analysis showed that significantly higher scores on both dimensions of the respondents from the age group of 25 to 35 years were obtained.

Table 5: The significance of divergences in the expression of results on the subscales of expected and perceived attributes of postal services, depending on the professional qualifications of the respondents

\begin{tabular}{|l|c|l|l|c|c|}
\hline $\begin{array}{c}\text { Expected attributes } \\
\text { scale }\end{array}$ & $\chi^{2}$ & $\boldsymbol{p}$ & $\begin{array}{c}\text { Perceived attributes } \\
\text { scale }\end{array}$ & $\chi^{2}$ & $\boldsymbol{p}$ \\
\hline Tangibles & 33.922 & $0.000^{* *}$ & Tangibles & 5.416 & 0.067 \\
\hline Reliability & 17.617 & $0.000^{* *}$ & Reliability & 0.149 & 0.928 \\
\hline Responsiveness & 13.867 & $0.000^{* *}$ & Responsiveness & 8.710 & $0.013^{*}$ \\
\hline Assurance & 31.739 & $0.000^{* *}$ & Assurance & 0.520 & 0.771 \\
\hline Empathy & 37.805 & $0.000^{* *}$ & Empathy & 7.023 & $0.030^{*}$ \\
\hline Average & 39.804 & $0.000^{* *}$ & Average & 1.259 & 0.533 \\
\hline
\end{tabular}


given a great unevenness of the sample when it comes to the educational level (Table 5), it was decided to consider only respondents from the following categories: high school (32.8\%), college (25.8\%) and subjects who have graduated from university $(33.3 \%)$ in consideration of the existence of statistical differences in severity scores. The respondents that completed a master level of education $(5.0 \%)$ as well as Ph.D. respondents (3.3\%) were excluded from this analysis.

A revision of the relevance of differences showed that statistically significant differences $(p<0.01)$ exist in all dimensions of the scale of the expected attributes of services, as well as the cumulative average. According to the amount of statistics, the biggest difference is obtained on the aggregate average on the Empathy dimension. A subsequent analysis showed that subjects who completed their high school education had significantly higher scores an all subscales except on the Reliability scale where subjects with university education level had significantly higher scores in comparison with the other two groups.

In addition, significant differences in severity scores according to the education level of respondents were obtained on a scale of perceived attributes, on the Responsiveness and Empathy sub-scales. The obtained differences were statistically significant at the level of $p<0.05$ while a subsequent analysis has shown that subjects with university level of education have significantly higher scores on the Responsiveness subscale. Respondents with high-school education level have significantly higher scores on the Empathy subscale.

Table 6: The severity of the expected attributes of postal services depending on the place of residence of the respondents

\begin{tabular}{|c|c|c|c|}
\hline Expected attributes & Place of residence & AS & SD \\
\hline \multirow{4}{*}{ Tangibles } & Belgrade region & 4.54 & 0.315 \\
\hline & Region of Vojvodina & 4.59 & 0.322 \\
\hline & Sumadija and Western Serbia & 4.62 & 0.323 \\
\hline & Southern and Eastern Serbia & 4.72 & 0.226 \\
\hline \multirow{4}{*}{ Reliability } & Belgrade region & 4.65 & 0.495 \\
\hline & Region of Vojvodina & 4.85 & 0.196 \\
\hline & Sumadija and Western Serbia & 4.59 & 0.358 \\
\hline & Southern and Eastern Serbia & 4.84 & 0.157 \\
\hline \multirow{4}{*}{ Responsiveness } & Belgrade region & 4.10 & 0.272 \\
\hline & Region of Vojvodina & 4.10 & 0.391 \\
\hline & Sumadija and Western Serbia & 4.27 & 0.463 \\
\hline & Southern and Eastern Serbia & 4.14 & 0.252 \\
\hline \multirow{4}{*}{ Assurance } & Belgrade region & 3.88 & 0.559 \\
\hline & Region of Vojvodina & 4.36 & 0.430 \\
\hline & Sumadija and Western Serbia & 4.17 & 0.661 \\
\hline & Southern and Eastern Serbia & 4.09 & 0.507 \\
\hline \multirow{4}{*}{ Empathy } & Belgrade region & 4.32 & 0.408 \\
\hline & Region of Vojvodina & 4.39 & 0.460 \\
\hline & Sumadija and Western Serbia & 4.36 & 0.559 \\
\hline & Southern and Eastern Serbia & 4.39 & 0.391 \\
\hline \multirow{4}{*}{ Average } & Belgrade region & 4.30 & 0.302 \\
\hline & Region of Vojvodina & 4.46 & 0.242 \\
\hline & Sumadija and Western Serbia & 4.40 & 0.349 \\
\hline & Southern and Eastern Serbia & 4.44 & 0.222 \\
\hline
\end{tabular}

Source: Authors' calculations

Table 6 shows the severity scores on the dimensions of the scale of the expected attributes of postal services, depending on the residence of the respondents. The highest score on the Tangibles dimension were observed in subjects from Southern and Eastern Serbia while the lowest score was observed in the respondents from the Belgrade region. As regards the Reliability dimension, the highest score was recorded by subjects from the Region of Vojvodina and respondents from South and East Serbia whereas the lowest score was recorded by the residents from Sumadija. The Responsiveness dimension records lower scores than the other dimensions of the scale and the most pronounced score is recorded among subjects who live in Sumadija and Western Serbia. On the Assurance dimension the best score was recorded by the respondents from the region of Vojvodina while the lowest score was recorded by the respondents from the Bel- 
grade region. The highest score on the Empathy dimension was recorded by the respondents from the region of Vojvodina and respondents from the South and East Serbia, while the lowest score was recorded among respondents from the Belgrade region. On an average of the entire scale of the expected attributes of the postal service, the highest score was obtained by the respondents from the Region of Vojvodina while the lowest was recorded by the respondents from the Belgrade region.

Given the fact that there is a large gap in the distribution of the sample according to the place of residence, the relevance of differences in the prominence of these scores was not checked.

Table 7: Prominence of perceived attributes of postal services depending on the place of residence of the respondents

\begin{tabular}{|c|l|c|c|}
\hline Expected attributes & \multicolumn{1}{|c|}{ Place of residence } & AS & SD \\
\hline \multirow{4}{*}{ Tangibles } & Belgrade region & 3.32 & 0.682 \\
\cline { 2 - 4 } & Region of Vojvodina & 3.27 & 0.565 \\
\cline { 2 - 4 } & Sumadija and Western Serbia & 3.54 & 0.696 \\
\cline { 2 - 4 } & Southern and Eastern Serbia & 3.26 & 0.173 \\
\hline \multirow{5}{*}{ Reliability } & Belgrade region & 3.53 & 0.745 \\
\cline { 2 - 4 } & Region of Vojvodina & 3.27 & 0.789 \\
\cline { 2 - 4 } & Sumadija and Western Serbia & 3.37 & 0.747 \\
\cline { 2 - 4 } & Southern and Eastern Serbia & 3.04 & 0.430 \\
\hline \multirow{5}{*}{ Responsiveness } & Belgrade region & 3.44 & 0.514 \\
\cline { 2 - 4 } & Region of Vojvodina & 2.91 & 0.612 \\
\cline { 2 - 4 } & Sumadija and Western Serbia & 2.95 & 0.824 \\
\cline { 2 - 4 } & Southern and Eastern Serbia & 2.97 & 0.386 \\
\hline \multirow{5}{*}{ Assurance } & Belgrade region & 2.94 & 0.617 \\
\cline { 2 - 4 } & Region of Vojvodina & 2.73 & 0.574 \\
\cline { 2 - 4 } & Sumadija and Western Serbia & 2.92 & 0.783 \\
\cline { 2 - 4 } & Southern and Eastern Serbia & 3.14 & 0.476 \\
\hline \multirow{5}{*}{ Empathy } & Belgrade region & 3.04 & 0.620 \\
\cline { 2 - 4 } & Region of Vojvodina & 2.73 & 0.657 \\
\cline { 2 - 4 } & Sumadija and Western Serbia & 3.31 & 0.778 \\
\cline { 2 - 4 } & Southern and Eastern Serbia & 2.87 & 0.366 \\
\hline \multirow{5}{*}{ Average } & Belgrade region & 3.25 & 0.458 \\
\cline { 2 - 4 } & Region of Vojvodina & 2.98 & 0.571 \\
\cline { 2 - 4 } & Sumadija and Western Serbia & 3.22 & 0.690 \\
\cline { 2 - 4 } & Southern and Eastern Serbia & 3.06 & 0.290 \\
\hline
\end{tabular}

Source: Authors' calculations

Table 7 shows the severity of scores on a perceived attributes scale of postal services depending on the place of residence of the respondents. As regards the tangibles dimension, the highest score was obtained by the respondents from Sumadija and Western Serbia while the lowest score was recorded among the respondents from Southern and Eastern Serbia. In case of the Reliability dimension, the most severe score was recorded by the respondents living in the Belgrade region and the lowest score was recorded among the residents from Southern and Eastern Serbia. In case of the Responsiveness dimension, the highest score is once again obtained from the respondents from the Belgrade region and the lowest one by the respondents from the region of Vojvodina. When it comes to Assurance dimension, the highest scores were recorded among the subjects from the Southern and Eastern Serbia and the lowest was recorded among the respondents from Sumadija and Western Serbia. Regarding the Empathy dimension, the highest score was obtained from the respondents from Sumadija and Western Serbia and the lowest score was recorded among respondents from the region of Vojvodina. When it comes to aggregate average of the entire scale of the observed attributes of the postal service, the highest score was obtained by the respondents from the Belgrade region and the lowest score was obtained by the respondents from the region of Vojvodina.

The significance of differences in severity scores on scales of expected and observed attributes of postal services according to the place of residence of the respondents was not checked for the reasons stated in the explanation of the previous table. 
Table 8: The significance of divergences in the prominence of results on the expected and perceived attributes subscales depending on the marital status of respondents

\begin{tabular}{|l|c|c|l|c|c|}
\hline Expected attributes scale & $\boldsymbol{Z}$ & $\boldsymbol{p}$ & \multicolumn{1}{|c|}{$\begin{array}{c}\text { Perceived attributes } \\
\text { scale }\end{array}$} & $\boldsymbol{Z}$ & $\boldsymbol{p}$ \\
\hline Tangibles & -3.599 & $0.000^{\star *}$ & Tangibles & -2.023 & $0.043^{*}$ \\
\hline Reliability & -7.332 & $0.000^{\star *}$ & Reliability & -0.130 & 0.897 \\
\hline Responsiveness & -2.869 & $0.004^{\star *}$ & Responsiveness & -3.480 & $0.001^{\star *}$ \\
\hline Assurance & -2.870 & $0.004^{\star *}$ & Assurance & -1.786 & 0.074 \\
\hline Empathy & -1.414 & 0.157 & Empathy & -5.436 & $0.000^{\star *}$ \\
\hline Average & -1.833 & 0.067 & Average & -0.985 & 0.325 \\
\hline
\end{tabular}

$d f=400 ; p<0.01 * * * p<0.05$; Source: Authors' calculations

In relation to the marital status of respondents (Table 8), statistically significant divergences were obtained on the following dimensions of the expected attributes scale of postal services: Tangibles, Reliability, Responsiveness and Assurance. All divergences were significant at the high $p<0.01$ level, while a subsequent analysis showed significantly higher scores on the Tangibles, Responsiveness and Assurance dimensions of the single respondents. Significantly higher scores were obtained within married respondents regarding the Reliability dimension. Statistically significant divergences in relation to the marital status of respondents were obtained for Responsiveness and Empathy dimensions on a scale of perceived attributes (at $p<0.01$ level), as well as on the Tangibles dimension (at $p<0.05$ level). It is also confirmed that single respondents have significantly higher scores when it comes to the Tangibles and Empathy dimensions, while the Responsiveness dimension obtained higher scores among married respondents.

Table 9: Significance of divergences in the prominence of results on the expected and perceived attribute subscales depending on the amount of monthly income of the respondents

\begin{tabular}{|l|c|c|l|c|c|}
\hline $\begin{array}{c}\text { Expected attributes } \\
\text { scale }\end{array}$ & $\chi^{2}$ & $\boldsymbol{p}$ & $\begin{array}{c}\text { Perceived attributes } \\
\text { scale }\end{array}$ & $\chi^{2}$ & $\boldsymbol{p}$ \\
\hline Tangibles & 29.679 & $0.000^{* *}$ & Tangibles & 24.946 & $0.000^{* *}$ \\
\hline Reliability & 12.148 & $0.016^{*}$ & Reliability & 16.968 & $0.002^{* *}$ \\
\hline Responsiveness & 12.020 & $0.017^{*}$ & Responsiveness & 27.517 & $0.000^{* *}$ \\
\hline Assurance & 33.872 & $0.000^{* *}$ & Assurance & 20.763 & $0.000^{* *}$ \\
\hline Empathy & 11.551 & $0.021^{*}$ & Empathy & 38.905 & $0.000^{* *}$ \\
\hline Average & 8.197 & 0.085 & Average & 21.806 & $0.000^{* *}$ \\
\hline
\end{tabular}

$d f=212 ; p<0.01^{* *} ; p<0.05^{*}$; Source: Authors' calculations

When it comes to the amount of the monthly income of the respondents (Table 9), due to the large discrepancies in the distribution of the sample according to this variable, in consideration of the existence of significant differences respondents who did not want to disclose the amount of their income were excluded from the analysis (47.0\%) and the analysis was performed on the rest of the sample of 212 subjects (13.0 $\%$ - RSD 40,001 - 50.000; 12.0\% - RSD 25.001 - 40,000; $11.5 \%$ - more than RSD 60,000, 10.0\% - RSD $15,001-25,000$; and 6.5\% - RSD 50,001-60,000).

The results of the study have shown that there are statistically significant differences on the scale of the expected attributes on all dimensions except for the cumulative average of the entire scale. The difference obtained on the Tangibles and Assurance sub-scale is high and significant at the $p<0.01$ level, while the other obtained differences are significant at the $p<0.05$ level. The subsequent analysis showed that significantly higher scores on the Tangibles and Responsiveness dimensions are observed in respondents from the group whose monthly revenue is from RSD 25,000 to 40,000 . When it comes to the Reliability dimension, significantly higher scores were found in subjects having monthly incomes from RSD 50,000 to 60.000. On the Assurance dimension, significantly higher scores are recorded among respondents having a monthly income from RSD 40,000 to 50,000, while in the Empathy dimension significantly higher scores were recorded among respondents with the lowest income, from RSD 15,000 to 25,000.

On the scale of perceived attributes of postal services, statistically most significant differences were obtained for all of the dimensions, as well asfor the cumulative average of the whole scale of perceived attributes. All of the obtained differences were high and significant at the $p<0.01$ level. The subsequent 
analysis showed that respondents with an income higher than RSD 60,000 had significantly higher scores on the Tangibles and Responsiveness dimensions and on the cumulative average scale of the perceived attributes. Significantly higher scores on the Reliability dimension were perceived in respondents with a monthly income from RSD 15,000 to 25,000 . When we talk about the Assurance dimension, significantly higher score was obtained among the respondents with a monthly income from RSD 50,000 to 60,000, while on the Empathy dimension the higher score was obtained among the respondents with a monthly income from RSD 25,000 to 40,000 .

Table 10: The significance of divergences in the prominence of results on the expected and perceived attribute subscales, depending on the social status of the respondents

\begin{tabular}{|l|c|c|l|c|c|}
\hline \multicolumn{1}{|c|}{$\begin{array}{c}\text { Expected attributes } \\
\text { scale }\end{array}$} & $\boldsymbol{Z}$ & $\boldsymbol{p}$ & $\begin{array}{c}\text { Perceived attributes } \\
\text { scale }\end{array}$ & $\boldsymbol{Z}$ & $\boldsymbol{p}$ \\
\hline Tangibles & -3.008 & $0.003^{\star *}$ & Tangibles & -1.932 & 0.053 \\
\hline Reliability & -4.956 & $0.000^{* *}$ & Reliability & -1.376 & 0.169 \\
\hline Responsiveness & -.455 & 0.649 & Responsiveness & -2.910 & $0.004^{\star *}$ \\
\hline Assurance & -1.184 & 0.236 & Assurance & -1.349 & 0.177 \\
\hline Empathy & -2.361 & $0.018^{*}$ & Empathy & -6.059 & $0.000^{\star *}$ \\
\hline Average & -1.239 & 0.215 & Average & -1.275 & 0.202 \\
\hline
\end{tabular}

$d f=400 ; p<0.01^{* *} ; p<0.05^{*}$; Source: Authors' calculations

Table 10 shows significant differences in severity scores on scales of expected and perceived attributes of postal services, depending on the social status of the respondents. Due to the existence of large imbalances of the sample according to this variable, it was decided to carry out an analysis of the whole sample and that the number of categories should be reduced to two - employed respondents and all other respondents (students, pensioners, farmers and unemployed respondents) as well as to carry out analysis of the significance of differences using the Mann-Whitney test. The results showed that significant differences in the scale of the expected attributes existed in the dimensions of Tangibles, Reliability and Empathy. The first two obtained differences were high and significant at $p<0.01$ level, while the third one was significant at the $p<0.05$ level. The severity scores confirmed that respondents from the other category (all other social categories) had higher scores on the Tangibles and Empathy dimensions while the employed respondents had higher scores on the Reliability dimension.

Statistically significant differences in severity scores according to the social status of the respondents were obtained on the Responsiveness and Empathy dimensions on the scale of perceived attributes of postal services. Both differences are high and significant at the $p<0.01$ level. Close to statistical significance, but also insignificant is the difference obtained for the Tangibles dimension. In the examination of the severity scores, it was found that employed respondents had a significantly higher score on the Responsiveness dimension while the respondents from the other category (all other social categories) have higher scores on the Empathy dimensions.

\section{Conslusion}

The total sample consisted of 400 respondents from the territory of Serbia. The survey was conducted in the period from the beginning of November 2016 to the end of January 2017. E-mail invitations and a questionnaire to participate in the study along with an explanation of the purpose for the experiments were sent to the respondents.

As we know, the Post had a rather conservative attitude on the market so it pointed out that marketing is not applicable in the postal sector. However, today the Post completely changed its attitude. The competition had a great influence featured in the new market.

It was necessary to invest in marketing activities, product differentiation, and in-house marketing, which has become the primary weapon in the fight against competitors in accordance with their capabilities, in order to cope with new circumstances. The Post must meet the needs of its customers in order to achieve higher efficiency, productivity and the market share in the today's competitive environment.

The most important thing is to maintain high levels of customer satisfaction and long-term relationship with them. The research gives us an insight into the current level of perceived quality of postal services by the users, as well as the connection that is present between the Post and its clients/users. 
Based on research we can conclude that customers expect more from elements such as equipment, various brochures, leaflets, but also on working time. We can conclude that it is necessary to invest more in elements of visual aids and, of course, to adjust working time to users. The users are the most important segment, so the Post has to improve the selection of employees. The management of Post should constantly insist on improving compliance processes of all service dimensions in order to achieve a higher level of skills in terms of providing the promised services than expected.

The most reliable method for measuring customer satisfaction is to perform research using questionnaires at least once a year. Research was conducted in major Serbian cities. These cities are the headquarters of financial and economic development and certainly have an impact on research results, particularly in terms of customer satisfaction. It should be noted that the purchasing power and the level of demand for most products and services is at the highest level in these cities, and that the most fierce competition exists among postal operators that are definitely aiming to get new customers.

In subsequent research it is certainly necessary to examine the attitudes of employees at Post offices. In addition, the demographic characteristics of the respondents and other consumer units should be taken as an important factor in conducting future research, in order to assess the quality and the level of postal services, as well as the satisfaction of employees. The results obtained through this kind of research cannot provide the Post with tangible benefits if appropriate management is not willing to modify the existing marketing strategies according to the results of the research.

It should be noted that modern Post should be directed towards understanding the requirements of its customers and solving the potential problems, so their perception of the quality of service is positive to an as high as possible extent. In further researching into the quality of postal services it is necessary to carry out a survey in which respondents are also the employed, i.e., the manager, the incumbents in the various functions, such as treasurer, controller, sales services, branch manager and others. Such research would provide a complete insight into the level of satisfaction in the postal sector.

The contribution of this paper lies is in the field of the development of methodological procedures for research of user satisfaction with postal services. For the future use of the proposed research it is necessary to ensure that the representativeness of the sample or the obtained results can be considered as purely indicative and do not represent an impartial basis for decision-making.

Random samples of existing users and new users are the target groups that should be included in the future research because they can provide us with useful information that will give us the answer to the question of what determines the priority of one postal operator in relation to other and in which direction relationships with customers should develop.

As a recommendation for subsequent research in the postal sector, it should be noted that there is a need for correction of the existing questionnaires, i.e., instruments for measuring the quality and the need for a new instrument for measuring the quality of services, but also their more frequent application and detailed analysis.

The aim of this study was to evaluate the satisfaction of users of postal services by examining the divergences that exist in the perception of expected and perceived attributes of services. The divergence obtained in this way becomes a measure of the quality of services and guidance of how to perform changes in order to provide a greater satisfaction of users. The quality of service is measured through five dimensions, i.e., attributes (expected and perceived): Tangibles, Reliability, Responsiveness, Assurance and Empathy. The results showed that the highest score for the expected attributes was obtained on the Reliability dimension, while on a scale of perceived attribute the highest score was obtained for the Tangibles dimension. The lowest score on both scales was obtained for the Assurance dimension. The results showed that divergences exist on all five attributes of postal services when it comes to divergences in scores on the scales of expected and perceived attributes of postal services. The biggest divergence was obtained for the Reliability dimension, while a minimum divergence exists on the Tangibles dimension. The range of the obtained divergence is not large and ranges from 1.16 up to 1.30 .

Checking divergences in severity scores on expected and perceived attributes subscales showed statistically significant divergences for all five measured dimensions, as well as for aggregated averages of the scales. According to the amount of obtained indicators, the highest divergence in expression exists regarding the Reliability dimension.

$\mathrm{H}_{1}$ Users of postal services expect more from the "Reliability" dimension of quality, which is confirmed by the above survey. $\mathrm{H}_{2}$ Users of postal services expect more from the "Assurance" dimension of quality, which is confirmed by the above survey. $\mathrm{H}_{3}$ Users of postal services expect more from the "Empathy" dimension of quality, which is confirmed by the above survey. $\mathrm{H}_{4}$ Users of postal services expect more from the "Responsiveness" dimension of quality, which is confirmed by the above survey. $\mathrm{H}_{5}$ Users of postal services expect more from the "Tangibles" dimension of quality, which is confirmed by the above survey. 


\section{REFERENCES}

[1] Ackere, V., Haxholdt, R., \& Larsen V. (2013). Dynamic Capacity Adjustments with reactive Customers. Omega,41(4), 689-705. DOI:10.1016/j.omega.2012.09.007

[2] Ambrosini, X., Boldron, F., \&Roy B.(2006).,,Universal Service Obligations in the Postal Sector Economic Learnings from Cross-Country Comparison“. In: Crew MA, Kleindorfer PR, editors. Progress toward Liberalization of the Postal and Delivery Sector. New York: Springer Science+ Business Media; Retrieved from http://www.springer.com/cda/content/document/cda_downloaddocument/9780387297439c2.pdf?SGWID=0-0-45-418415-p88893028

[3] Bass FM.(1969), New Product growth model for consumer durables, Manage Sci.15(5):215-227. DOI:10.1287/mnsc.15.5.215

[4] Berry, L.,\& Jams,L.,(1995), Services Marketing IS Different Magazine, 23, 236. DOI:10.1177/009207039502300402

[5] Bryaland, A., \& Curry, A., (2001) Service improvements in public services using SERVQUAL, Managing Service Quality: An International Journal, 11(6), 389-401, DOI:10.1108/09604520110410601

[6] Bielen, F.,\&Demoulin, N.,(2007). Waiting Time Influence on the Satisfaction-Loyalty Relationship in Service, Managing Service Quality,17(2), 174-193.

[7] Blagojevic M., Selmic M., Macura D., \&Sarac D. (2013). Determining the number of postal units in the network - Fuzzy approach,Serbia case study, Expert Systems with Applications, 40, 4090-4095. DOI:10.1016/j.eswa.2013.01.038

[8] Dobrodolac M., Lazarevic D., Svadlenka L., \&Zivanovic M., (2016). A study on the competitive strategy of the universal postal service provider. Technology Analysis \& Strategic Management, 28(8), 935-949. DOI:10.1080/09537325.2016.1180357

[9] Dobrodolac M., Ralevic P., Svadlenka L., \&Radojicic V., (2016). Impact of a New Concept of Universal Service Obligations on Revenue Increase in the Post of Serbia. PROMET-Traffic\&Transportation, 28(3), 235-244.

[10] Evans J.,\& Anil M., (2005). The value of online surveys. Internet research, 15(2), 195-219.

[11] Garrard, Francesca \& Narayan, Harini. (2013). Assessing obstetric patient experience: A SERVQUAL questionnaire. International journal of health care quality assurance. 26. 582-92. DOI:10.1108/IJHCQA08-2011-0049

[12] Grubic, G., Ratkovic, M. \&Paunovic, L. (2013), Vertical portal e-business model applied for construction industry in South-East Europe. Actual Problems of Economics, 4(143), 224-236.

[13] Grubor, A., \& Milicevic, N. (2015). Merenje dostupnosti proizvoda svakodnevne potrošnje. Industrija, 43(1), 53-71. DOI:10.5937/industrija43-6683

[14] Grubic, G., Ratkovic, M. (2012) The analysis of available ERP solutions and trends in industry of management information systems. Praktični menadžment, 3(4), 86-92

[15] Hill, N.\& Alexander, J. (2006). Handbook of customer satisfaction and loyalty measurement", Gower Publishing Limited, Hampshire.

[16] Ilyas, A., et al. (2013). Assessing the Service Quality of Bank Using SERVQUAL Model. Interdisciplinary Journal of Contemporary Research In Business, 4(11), 390-400.

[17] Jaag, C. (2014). Postal-sector policy: From monopoly to regulated competition and beyond. Utilities Policy, 31, 266-277.DOI:10.1016/j.jup.2014.03.002

[18] Jovanovic B., Grbic T., Bojovic N., Kujacic M., \& Sarac D. (2015). Application of ANFIS for the Estimation of Queuing in a Postal Network Unit: A Case Study, ActaPolytechnicaHungarica. 12(7), 25-40.

[19] Kabene, S. M., Orchard, C., Howard, J. M., Soriano, M. A., \& Leduc, R. (2006). The importance of human resources management in health care: a global context. Human Resources for Health, 4, DOI:10.1186/1478-4491-4-20

[20] Kaye, M., \& Dyason, M. (2013). Delivering "more for less" in the public sector: a criminal justice system case study, Proceeding of 14 International Symposium on Quality, Quality against recession, Rovinj, pp. 571-581. ISBN 978-953-57036-3-1.

[21] Kiumarsi, S., Jayaraman,K., \&Salmi-Mohd,I., (2015). Service Quality and Innovation in Malaysian Post Offices: An Empirical Study, DOI: 10.1002/joe.21645

[22] Knezevic, N., Macura, D., \&Bojovic N., (2014). Primena A 'WOT metode za izbor scenarija razvoja poštanskih usluga u Republici Srbiji, Tehnika-Menadžment, str. 158-163

[23] Kujacic, M. D., Unterberger, M. P., Sarac, D. D., \& Jovanovic, B. B. (2014). Primena metodologije 'Process management' u obavljanju finansijskih usluga JP 'Pošta Srbije'. Tehnika, 69(6), 1051-1059. DOI:10.5937/tehnika1406051K 
[24] R., I.,\& M., (2011). Bank service quality: comparing Canadian and Tunisian customer perceptions, International Journal of Bank Marketing, Vol. 29 Issue: 3, pp.224-246, DOI:10.1108/02652321111117502

[25] Lee, H. J., \& Yang, K, (2013), Interpersonal service quality, self-service technology (SST) service quality, and retail patronage, Journal of Retailing and Consumer Services, 20, 51-57

[26] Mahapatra, N. S. (2014). Empirijska analiza razloga nezadovoljstva kupaca i razlozi zbog kojih kupci pokazuju nezadovoljstvo.Serbian Journal of Management, 9(1), 71-89. DOI:10.5937/sjm9-5181

[27] Maricic, B. (2005), Ponašanje potrošača, EkonomskiFakultet, Beograd.

[28] Maricic, B., Veljkovic, S., \&Djordjevic, A. (2012). Merenje satisfakcije potrošača.Marketing, 43(4), 235244. DOI::10.5937/markt1204235M

[29] Matuskova, M.,\& Madlenakova, L., (2017). The Impact of the Electronic Services to the Universal Postal Services, 16th Conference on Reliability and Statistics in Transportation and Communication, RelStat'2016, 19-22 October, 2016, Riga, Latvia ,258-266, DOI: 10.1016/j.proeng.2017.01.111

[30] Miletic, Z., (2013), "Troškovni utjecaj novih davatelja usluga kroz alternativne ulazne politike i heterogene korisnike usluga, Ekonomska misao i praksa, 2, 469-498.

[31] Milisavljevic, M., (2014), Strategijski marketing, Beograd, Ekonomski fakutet

[32] Milosevic, I., \&Rodic, V. (2015), Importance of the environment in the value system in Serbia: Survey results., Issue 150, 113-127. DOI:10.2298/ZMSDN1550113M

[33] Panda, R. K. \& Kondasani, R. K. R. (2014). Assessing customers' perceived service quality in private sector banks in India. Serbian Journal of Managemnt 9(1): 91-103, DOI:10.5937/sjm9-4511

[34] Petrovic, V.(2016). Postal system strategy selection by applying multicriteria analysis.Yugoslav Journal Of Operations Research, 16(2).

[35] Pilinkiene, V., Deltuvaite, V., Daunoriene, A., \& Gaidelys, V. (2017). Competition in Postal, Courier and Financial Services Industries. In Competitiveness Creation and Maintenance in the Postal Services Industry (pp. 65-274). Springer, Cham., DOI:10.1007/978-3-319-31906-3_3

[36] Pindzo, R., \&Loncar, I. (2013). Analiza kvaliteta hotelskih usluga primenom SERVQUAL metodologije. Ekonomika preduzeća, 61(3-4), 199-211.DOI:10.5937/ekopre1304199P

[37] Pitia, N., Singh, G., \& Naz, R. (2013). Postal Service Reforms in Solomon Islands of the South Pacific: Evaluating Consequences for Public Service Delivery and Customer Satisfaction. International Journal of Public Administration, 36(12), 821-830.DOI:10.1080/01900692.2013.795160

[38] Parasuraman, A., Zeithaml, V. A., \& Berry, L. L. (1988). Servqual: A multiple-item scale for measuring consumer perc. Journal of retailing, 64(1), 12.

[39] Rakesh, R. (2012). Quality assessment of banking industry using SERVQUAL model.Indian Streams Research Journal, 2(2),1-4. DOI : 10.9780/22307850

[40] Ralevic, P., Dobrodolac, M., \& Markovic, D. (2016). Using a nonparametric technique to measure the cost efficiency of postal delivery branches. Central European Journal of Operations Research, 24(3), 637-657. DOI:10.1007/s10100-014-0369-0

[41] Ratkovic, M. \&Grubic, G. (2011), Promene u marketingu i komunikaciji usled primene savremenih informacionih tehnologija. Ekonomika, 1, 67-79.

[42] Ratkovic, M. C., Krasulja, N. D., \&Garaca, N. (2013). Upravljanje odnosima sa kupcima kao mogućnost unapređenja savremenog koncepta marketinga. Kultura, (139), 381-395.

[43] Regulation on General Conditions for the Provision of Postal Services, "Official Gazette of RS".no. 24/2010, 58/2010, 2/2011, 13/2011, 65/2011, 93/2013 i 97/2015

[44] Roopchund, R.,\& Boojhawon, S., (2014), "Applying the SERVQUAL Model in Postal Services : A Case Study of Mahebourg Mauritius Post Services Ltd.", The International Journal Of Business \& Management, 2( 7), 222-235.

[45] Roslan, N. A. A., Wahab, E., \& Abdullah, N. H. (2015). Service Quality: A case study of logistics sector in Iskandar Malaysia using SERVQUAL Model. Procedia-Social and Behavioral Sciences, 172, 457-462., DOI: 10.1166/asl.2015.6243.

[46] Sarac D., Dupljanin, Dj., \& Unterberger M., (2014). Istraživanje zadovoljstva korisnika finansijskim uslugama i poštansko-finansijska inkluzija, Simpozijum POSTEL 2014. godina. Retrieved from http://postel.sf.bg.ac.rs/simpozijumi/POSTEL2014/RADOVI\%20PDF/Menadzment\%20procesa\%20u\%20 postanskom\%20i\%20telekomunikacionom\%20saobracaju/3.\%20D.\%20Sarac,\%20Dj.\%20Dupljanin,\%20 M.\%20Utenberger.pdf

[47] Sarac, D., Kopic, M., Mostarac, K., Kujacic, M., \& Jovanovic, B. (2016). Application of Set Covering Location Problem for Organizing the Public Postal Network. Promet - Traffic\&Transportation, 28(4), 403413. Retrieved from http://hrcak.srce.hr/165541

[48] Sarac, D., Kujacic, M., \& Jovanovic, B. (2013). Strategija razvoja i portfolio e-servisa u pošti, Info M, 12(47), 25-31. 
[49] Schuster, P., (2013). One for all and all for one: privatization and Universal Service provision in the postal sector, Applied Economics, 45, 3667-3682 DOI:10.1080/00036846.2012.727982

[50] Sokolov-Mladenovic, S., \& Cuzovic, S. (2015). Kvalitet usluga u maloprodaji kao osnova donošenja odluka o kupovini. Marketing, 46(1), 26-35. DOI:10.5937/markt1501026S

[51] Vunjak, N., \& Kovacevic, Lj. (2011), "Bankarstvo: bankarski menadžment", Subotica: Ekonomski fakultet.

Received: 2017-05-26

Accepted: 2018-01-09

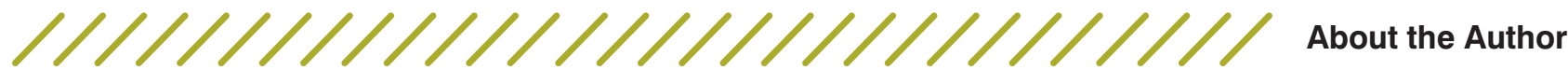

\section{Marko Pavlovic \\ e-mail: markopavlovic82@mts.rs}

Born in 1982 in Belgrade. A Ph.D. student at the "UNION - Nikola Tesla" University of Belgrade. He has participated in several international conferences and has published scientific papers in journals recognized by the Ministry of Education. So far, he has published more than twenty scientific papers. He was elected and worked as an assistant at the Faculty of Economics and Engineering Management in Novi Sad for the period of three school years. Employee of Posta Srbije. His area of interests are: management, human resources management, banking and customer relations.

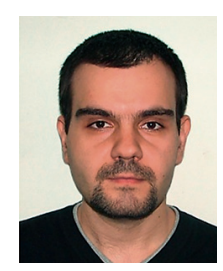

\section{Radica Bojicic e-mail: radica.bojicic@pr.ac.rs}

Assistant professor at the Faculty of Economics, University of Prishtina, Kosovska Mitrovica. She lectures at the courses of Mathematics, Statistics, Operations Research majors at the undergraduate člevel, Econometrics at master and the methods and techniques of scientific research and analysis on doctoral level studies. She is the author of several papers on the SCI list. She has participated in several international conferences in the country and abroad. Her research interests include linear algebra, special array class, mathematical analysis and differential equations.

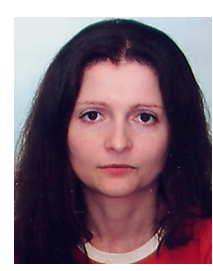

\section{Milijanka C. Ratkovic e-mail: milijanka.ratkovic@fpsp.edu.rs}

MilijankaRatkovic is an Associate Professor at the Faculty of Business Studies and Law, "UNION - Nikola Tesla" University of Belgrade and the Faculty of Sport Management, University of DonjaGorica in Podgorica. She teaches Marketing, Consumer Behaviour and Marketing in sport courses. She is the author of more than seventy articles published in national and international journals, conference papers, including chapters in monographs and monographic publications.

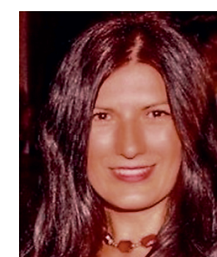

